\title{
Clinical applications of ozone in horses of Mexico [abstract]
}

\section{Eduardo Flores-Colin, Susana Gabriela Gayon-Amaro}

Ozein Vet Klinike

\section{ABSTRACT}

\section{OPEN ACCESS}

\section{Citation}

Flores-Colin E, Gayon-Amaro SG. Clinical applications of ozone in horses of Mexico [abstract]. Proceedings of The World Conference on Ozone Therapy in Medicine, Dentistry and Veterinary. Ancona (Italy). September 22nd - 23rd - 24th , 2017. J Ozone Ther. 2019;3(4):15. doi: 10.7203/ jo3t.3.4.2019.15420

\section{Academic Editor}

Jose Baeza-Noci,

School of Medicine, Valencia University, SPAIN

\section{Editor}

World Federation of Ozone Therapy, Bolgna, ITALY

\section{Received}

June 17, 2019

\section{Accepted}

December 08, 2019

\section{Published}

December 30, 2019

\section{Intellectual Property}

Eduardo Flores-Colin.

This is an open access article distributed under the terms of the Creative Commons Attribution License (CC BY 4.0), which permits unrestricted use, distribution, and reproduction in any medium, provided the original author and source are credited.

\section{Author Information}

Email: mvzeduardo@msn.com
The industry of equines has grown exponentially in the last 30 years as well as medicine, which is why it is essential to have cutting-edge treatments to accelerate recovery processes in both: time and quality. In the last 8 years, we have implemented treatments based on ozone therapy and translational therapies such as ozone therapy (OP) and ozonated PRP.

Athletes horses suffer injuries associated with the different disciplines of the equestrian environment but some walking horses or geriatricians present chronic diseases and injuries that require quality care for their rehabilitation [1].

In addition to diseases, it is necessary to emphasize that OP has been an excellent option for those athlete horses that need to improve their metabolism or to increase the energy reserves and oxygenation to fulfill their activities in the tracks.

The following are the diseases and routes of administration that have been used and developed to treat horses in our group:

- MAHT and mAHT: Performance improvement and pain Degenerative joint disease [2]

- Ozonated distilled water intra articular injection: Arthritis and DJD, back problems, tendonitis and desmitis

- Local gas injection, OP and ozonized PRP: Stiffness of the skeletal structure

Hyper perfusion with ozonated distilled water via radial or brachial vein: Hoof diseases and laminitis

Local lavages and ozonated oil (3): Corneal ulcers, sinusitis, skin diseases.

Discussion. Compared with conventional therapies, ozone and its combinations showed to be better options for treatment

Conclusion. OP and translational medicine have proven to be the best way to improve the health of horses

\section{References:}

1. Hinchcliff KW, Kaneps AJ, Geor RJ, Equine Sports Medicine \& Surgery. Second Edition. USA. Saunders Elsevier; 2014. p 262-265.

2. Menéndez CS, González AR, Ledea LO, Hernández RF, León FO, Díaz GM. Ozono: Aspectos básicos y aplicaciones clínicas. Primera edición. Cuba. Editorial CENIC Centro Nacional de Investigaciones Científicas; 2008.

3. Vigna I, Menéndez CS. Aplicación de la ozonoterapia en diferentes enfermedades oftalmológicas: estudio de 59 casos. RECVET. 2007; 2(11):1-11 